\title{
Effect of Date of Sowing and Climate Change Variables on Greengram [Vigna radiata (L.) Wilczek] Anthracnose Caused by Colletotrichum truncatum
}

\author{
G. Rajashree $^{1 *}$, M. B. Patil ${ }^{1}$, D. S. Aswathanaryana ${ }^{1}$, K. Mallikarjun ${ }^{1}$ \\ and A. G. Sreenivas ${ }^{2}$ \\ ${ }^{1}$ Department of Plant Pathology University of Agricultural Sciences, Raichur-584100, India \\ ${ }^{2}$ Department of Agricultural Entomology, University of Agricultural Sciences, \\ Raichur-584100, India \\ *Corresponding author
}

A B S T R A C T

\begin{tabular}{l} 
Ke y w o r d s \\
$\begin{array}{l}\text { Greengram, } C \text {. } \\
\text { truncatum, sowing } \\
\text { dates, rainfall, } \\
\text { relative humidity, } \\
\text { carbon dioxide and } \\
\text { temperature }\end{array}$ \\
\hline Article Info \\
\hline $\begin{array}{l}\text { Accepted: } \\
\text { 12 February } 2020 \\
\text { Available Online: } \\
\text { 10 March } 2020\end{array}$ \\
\hline
\end{tabular}

Greengram is an important pulse crop of India and being affected by anthracnose disease. The experiment was conducted to study the influence of weather variables on anthracnose disease severity during Kharif, 2018 with three different dates of sowing viz., on $29^{\text {th }}$ July, $8^{\text {th }}$ August and $13^{\text {th }}$ August 2018. Disease severity was minimum in the crop sown on $29^{\text {th }}$ July when compared with crop sown on $13^{\text {th }}$ August due to favourable conditions led to build up the inoculum which has spread and caused more disease. The effect of $\mathrm{CO}_{2}$ and temperature was studied in the open top chambers (OTCs) maintained by Centre of Climate Studies, Main Agricultural Research Station (MARS), Raichur under five sets of treatments. Among them, ambient $\mathrm{CO}_{2}$ at $410 \pm 25 \mathrm{ppm}$ with $2{ }^{\circ} \mathrm{C}$ rise in temperature showed higher disease severity of 7.00 per cent with reduced growth parameters of greengram compared to open plot experiment.

\section{Introduction}

Greengram [Vigna radiata (L.) Wilczek] commonly known as mung bean is an important pulse crop of India cultivated mainly in Kharif season. It is also considered as "Golden Bean" because of its nutritional values and suitability for increasing the soil fertility by way of addition of nitrogen (30 $\mathrm{kg} / \mathrm{ha} / \mathrm{annum}$ ) (Murakami et al., 1991). Greengram is a rich source of protein (23-24 $\%)$, carbohydrate (54-56\%), minerals (4\%) and vitamins (3\%) (Afzal et al., 2008). In India the area of greengram is 40.7 lakh ha with a production of 19.01 lakh tonnes and $467 \mathrm{~kg} / \mathrm{ha}$ of productivity. Karnataka stands $3^{\text {rd }}$ position in area and Rajasthan (17.19 lakh ha) stands first position followed by 
Maharashtra (4.53 lakh ha ). In Karnataka, the area under greengram cultivation is 3.97 lakh hectares with a production of 0.96 lakh tonnes and an average productivity of $242 \mathrm{~kg}$ per hectare (Anonymous, 2018). The crop being affected by anthracnose is an important fungal disease. In India, the greengram anthracnose was first reported from Jorhat of Assam state in 1951 (Majid, 1953). The disease has been reported from all major mung bean growing regions of India in mild to severe form. Losses in yield due to anthracnose have been estimated to be in the range of 24 to 67 per cent (Deeksha and Tripathi, 2002) and 18.2 to 86.57 per cent disease index of anthracnose have been reported in Northern Karnataka (Laxman, 2006).

The yield losses caused by anthracnose is proportional to the disease severity and varies depending on the stage of infection and environmental conditions. To overcome some of these problems, the present investigations were undertaken to study the effect of sowing dates and weather factors in natural epiphytotic conditions, similarly effect of $\mathrm{CO}_{2}$ and temperature on severity of the disease to understand their practical utility in integrated disease management strategy of anthracnose.

\section{Materials and Methods}

Effect of date of sowing on the severity of anthracnose and correlation with weather factors

The influence of weather variables (temperature, relative humidity, rainfall, rainy days, sun shine hours and wind velocity) on greengram anthracnose disease intensity was studied during Kharif, 2018. The susceptible greengram variety Selection 4 was sown. The three different dates of sowing were taken on $29^{\text {th }}$ July, $8^{\text {th }}$ August and $13^{\text {th }}$ August as treatments with seven replications each. Randomized complete block design was used with a spacing of $45 \times 15 \mathrm{~cm}$. Package of practices was followed but except for anthracnose disease. Observations on greengram anthracnose disease severity were recorded starting at its first appearance and further at weekly intervals using 0-9 scale till the end of crop. The data on weather parameters of the corresponding meteorological weeks during experiment period was obtained from the Meteorological division, MARS, UAS, Raichur and correlated with anthracnose disease intensity.

Effect of carbon dioxide $\left(\mathrm{CO}_{2}\right)$ and temperature on severity of anthracnose

Open top chambers (OTCs) are widely used to study the effects of elevated $\mathrm{CO}_{2}$ and other atmospheric gases on vegetation. They are plastic enclosures, with an open top, constructed of an aluminium frame covered by panels of polyvinyl chloride plastic film. Air is pulled into the bottom of the chamber, enriched with $\mathrm{CO}_{2}$ and then blown through the open top of the chamber.

The study was conducted in the OTCs maintained by Centre of Climate Studies, MARS, Raichur under five sets of treatments. T1 : Elevated $\mathrm{CO}_{2}$ at $550 \pm 25$ ppm with normal temperature, T2 : Elevated $\mathrm{CO}_{2}$ at 550 \pm 25 ppm with $2^{\circ} \mathrm{C}$ rise in temperature, $\mathrm{T} 3$ : Ambient $\mathrm{CO}_{2}$ at $410 \pm 25 \mathrm{ppm}$ with $2^{\circ} \mathrm{C}$ rise in temperature, $\mathrm{T} 4$ : Reference open top chamber and T5 : Open plot

In OTCs, susceptible greengram variety (Selection - 4) was sown in the pots. Each pot was sown with seeds and maintained three plants. For each treatment four replications was maintained. Disease severity of anthracnose was recorded at 45 days after sowing. Followed by weekly interval using 0 9 scale. In addition to this observations on growth parameters were recorded. 


\section{Results and Discussion}

\section{Effect of dates of sowing on the severity of anthracnose and it's correlation with weather factors}

Always there will be seasonal influence on the disease development; similarly anthracnose in greengram is not an exception. Therefore influence of weather parameters on anthracnose development in different dates of sowing was studied.

The experiment result showed that, per cent disease index varied from 7.50 in the $31^{\text {st }}$ Standard Meteorological Week (SMW) under first date of sowing to 69.65 PDI in the $41^{\text {st }}$ SMW under third date of sowing. The severity increased slowly and reached the incidence of 69.65 per cent. The least average PDI was recorded on crop sown on $29^{\text {th }}$ July (28.58) and while the highest PDI was recorded on crop sown on $13^{\text {th }}$ August (39.10) (Table 1).

In the first date of sowing, the per cent disease index of anthracnose started with 7.50 and gradually increased with the stage of the crop upto 58.02 PDI. There was sudden increase in the anthracnose severity from 18.50 to 28.32 during $33^{\text {rd }}$ and $34^{\text {th }}$ SMW due to minimum temperature of $23.00{ }^{\circ} \mathrm{C}$ with rainfall of $18.80 \mathrm{~mm}$ and relative humidity (RH I) of 85.30 to 87.00 per cent were most favourable for the disease development.

The reason for increase in the disease severity of upto 58.02 during $38^{\text {th }}$ SMW may be attributed to min temperature $\left(22.70{ }^{\circ} \mathrm{C}\right)$, high rainfall $(47.00 \mathrm{~mm})$ with 83.40 per cent morning relative humidity and 55.00 per cent evening relative humidity (Table 2a) (Fig. 1) which might have helped sporulation, dissemination and germination of conidia and resulted in maximum disease development. The disease severity varied from 17.50 to
63.23 PDI in the second date of sowing $\left(8^{\text {th }}\right.$ August). Sudden increase in disease severity from 24.90 to 36.42 per cent was noticed during $35^{\text {th }}$ SMW due to high rainfall of 21.20 $\mathrm{mm}$ and high morning $(89.00 \%)$ and evening relative humidity $(54.30 \%)$ and also during $39^{\text {th }}$ SMW there was a sudden increase in disease severity from 49.21 to 57.65 per cent due to high morning relative humidity $(87 \%)$, evening relative humidity $(53 \%)$ and good rainfall of $21.60 \mathrm{~mm}$ (Table 3a) (Fig. 2) which provided congenial condition for sporulation and germination of conidia followed by infection.

In the third date of sowing, the disease severity varied from 18.50 to 69.65 PDI. The highest disease severity was observed during $41^{\text {st }} \mathrm{SMW}$ due to the minimum temperature of $20.80{ }^{\circ} \mathrm{C}$, rainfall of $3.2 \mathrm{~mm}$ and morning relative humidity of 71.00 per cent prevailed during the maturity stage of the crop. Sudden increase in disease severity was noticed between $38^{\text {th }}(46.14 \%)$ to $39^{\text {th }}$ SMW (56.11 $\%)$ due to high rainfall of about 21.30 to $47.00 \mathrm{~mm}$ and high morning and evening relative humidity of about 83.00 to 87.00 per cent and 53.00 to 55.00 per cent respectively (Table 4a) (Fig. 3).

The correlation studies between weather factors with the disease severity revealed that, the individual weather parameters like maximum temperature, minimum temperature, morning relative humidity, evening relative humidity were showed negative correlation. The weather parameter rainfall and sunshine hours were positively correlated with the per cent disease index in all the three different dates of sowing. The individual weather factor may not be most favourable for the disease development however the interaction between the weather parameters have favoured the disease progress which resulted in the highest disease severity (Table 2b, 3b and 4b). 
The individual weather parameters like rainfall $(\mathrm{r}=0.543)$ and sunshine hours $(\mathrm{r}=$ 0.728) showed positive correlation with disease severity in the first date of sowing. The interaction between the weather parameters like morning relative humidity and rainfall with that of the per cent disease index showed the positive correlation $(r=0.311)$ and also the interaction between weather parameters like sunshine hours and maximum temperature showed the positive correlation ( $\mathrm{r}$ $=0.375$ ).

In the second date of sowing, sunshine hours $(\mathrm{r}=0.830)$ showed significant positive correlation and also the interaction between the weather parameters like sunshine hours with that of maximum temperature $(r=0.578)$ and minimum temperature $(\mathrm{r}=0.295)$ and morning relative humidity $(\mathrm{r}=0.423)$ and evening relative humidity $(\mathrm{r}=0.378)$ with that of rainfall showed positive correlation hence, the moderate disease severity was recorded. The sunshine hours $(r=0.818)$ showed significant positive correlation in the third date of sowing. The interaction between the weather parameters like sunshine hours with that of minimum temperature $(r=0.131)$, morning relative humidity with that of minimum temperature $(\mathrm{r}=0.209)$ and rainfall $(r=0.475)$ and evening relative humidity with minimum temperature $(r=0.402)$ and rainfall $(\mathrm{r}=0.441)$ have shown positive correlation due to which the maximum disease severity was recorded.

Hence by this we can say that the first date of sowing is the best to get a good crop yield with low disease severity because of high temperature, low rainfall and moderate relative humidity.

The results were similar to the observations made by Kulkarni and Benagi (2012) who studied the effect of sowing time and corresponding weather factors on anthracnose severity. The crop sown during $4^{\text {th }}$ June to $11^{\text {th }}$ June recorded lesser severity of anthracnose which reflected on obtaining more grain yield of greengram compared to the crop sown during $18^{\text {th }}$ June and subsequent weeks. The late sown crop suffered more because of coincidence of the favourable period like moderate temperature coupled with higher humidity and frequent rains with stage of the crop. Mangilal (2014) recorded the favourable temperature for development of anthracnose were 22.07 to $22.35^{\circ} \mathrm{C}$ (minimum) and 26.78 to $27.5^{\circ} \mathrm{C}$ (as maximum), the RH 87 per cent with high rainfall and reported that development of anthracnose exhibited a positive correlation with all the factors studied during the $3^{\text {rd }}$ and $5^{\text {th }}$ week disease severity was suddenly high when relative humidity and temperatures were high and rainfall was more which favored the development of anthracnose.

Effect of carbon dioxide and temperature on anthracnose disease severity and greengram growth parameters

\section{Effect of carbon dioxide and temperature on disease severity}

Effect of different treatments of carbon dioxide and temperature were studied on greengram anthracnose severity. The results revealed that at ambient $\mathrm{CO}_{2}$ and elevated $\mathrm{CO}_{2}$ and in combination with increased temperature of $2{ }^{\circ} \mathrm{C}$ has aggrevated the disease. Among five treatments, Ambient $\mathrm{CO}_{2}$ at $410 \pm 25 \mathrm{ppm}$ with $2^{\circ} \mathrm{C}$ rise in temperature $\left(\mathrm{T}_{3}\right)$ showed higher disease severity of 7.00 per cent which was significantly superior over other treatments with early infection showing $\mathrm{red} / \mathrm{brown}$ lesions on leaves and stem. This was followed by elevated $\mathrm{CO}_{2}$ at $550 \pm 25$ ppm with $2{ }^{\circ} \mathrm{C}$ rise in temperature $\left(\mathrm{T}_{2}\right)$ showed the disease severity of 3.75 per cent. The least disease severity was observed in open plot $\left(\mathrm{T}_{5}\right)$ with 2.50 per cent (Table 5) (Fig. 4). 


\section{Effect of carbon dioxide and temperature on growth parameters}

The crop yields have been decreased greatly due to the changing climatic conditions mainly because of the increasing temperature and increasing concentration of $\mathrm{CO}_{2}$ in the atmosphere. Effect of carbon dioxide on growth parameters viz., height of the plant, number of leaves per plant and number of pods per plant were observed under the open top chambers during the present investigation.

Growth parameters such as maximum plant height $(33.80 \mathrm{~cm})$, number of leaves $(31.20)$ and number of pods (19.20) were observed in $\mathrm{T}_{5}$ treatment (open plot) followed by $\mathrm{T}_{4}$ (Reference open top chamber) and the minimum height of the plant $(29.00 \mathrm{~cm})$, number of leaves (24.60) and number of pods (12.40) were observed in $\mathrm{T}_{3}$ (Ambient $\mathrm{CO}_{2}$ at $410 \pm 25 \mathrm{ppm}$ with $2{ }^{\circ} \mathrm{C}$ rise in temperature) followed by $\mathrm{T}_{1}\left(\right.$ Elevated $\mathrm{CO}_{2}$ at $550 \pm 25 \mathrm{ppm}$ with normal temperature) and $\mathrm{T}_{2}$ (Elevated
$\mathrm{CO}_{2}$ at $550 \pm 25 \mathrm{ppm}$ with $2{ }^{\circ} \mathrm{C}$ rise in temperature). These results may be due to low level of $\mathrm{CO}_{2}$ and temperature in $\mathrm{T}_{5}$ and $\mathrm{T}_{4}$ which helped in good growth of the plants and the increased temperature in $\mathrm{T}_{3}$ resulted in decreased height, number of leaves and pods with increased disease severity. The elevated $\mathrm{CO}_{2}$ and temperature in $\mathrm{T}_{1}$ and $\mathrm{T}_{2}$ decreased, the height, number of leaves, number of pods per plant and increased the disease severity (Table 5) (Fig. 4).

The results were slightly similar with research work of Jeong and Sung (2010) who investigated four major diseases of chilli pepper including two fungal diseases, anthracnose and Phytophthora blight and two bacterial diseases, bacterial wilt and bacterial spot under future climatic conditions in growth chamber. They reported that, at elevated $\mathrm{CO}_{2}$ and temperature, infection ability of two fungal diseases did not change significantly but the severity of bacterial diseases was increased.

Table.1 Severity of greengram anthracnose on different dates of sowing during Kharif 2018

\begin{tabular}{|c|c|c|c|c|}
\hline \multirow[t]{2}{*}{ Sl. No. } & \multirow[t]{2}{*}{ SMW * } & \multicolumn{3}{|c|}{ Anthracnose severity (PDI) } \\
\hline & & $\begin{array}{l}1^{\text {st }} \text { DOS } * * \\
\left(29^{\text {th }} \text { July }\right)\end{array}$ & $\begin{array}{c}2^{\text {nd }} \text { DOS } * * \\
\left(8^{\text {th }} \text { August }\right)\end{array}$ & $\begin{array}{l}3^{\text {rd }} \text { DOS ** } \\
\left(13^{\text {th }} \text { August }\right)\end{array}$ \\
\hline 1 & 30 & 0.00 & - & - \\
\hline 2 & 31 & 7.50 & - & - \\
\hline 3 & 32 & 16.43 & 0 & - \\
\hline 4 & 33 & 18.50 & 17.50 & 0 \\
\hline 5 & 34 & 28.32 & 24.90 & 18.50 \\
\hline 6 & 35 & 36.75 & 36.42 & 26.32 \\
\hline 7 & 36 & 42.12 & 39.65 & 33.65 \\
\hline 8 & 37 & 49.65 & 42.56 & 40.58 \\
\hline 9 & 38 & 58.02 & 49.21 & 46.14 \\
\hline 10 & 39 & - & 57.65 & 56.11 \\
\hline 11 & 40 & - & 63.23 & 61.02 \\
\hline 12 & 41 & - & - & 69.65 \\
\hline
\end{tabular}


SMW * - Standard Meteorological Week; DOS ** - Date of sowing

Table.2a The data of weather parameters and per cent disease index of greengram anthracnose during crop sown on $29^{\text {th }}$ July, 2018 ( $1^{\text {st }}$ DOS)

\begin{tabular}{|c|c|c|c|c|c|c|c|c|c|c|}
\hline \multirow[t]{2}{*}{$\begin{array}{l}\text { Sl. } \\
\text { No }\end{array}$} & \multirow[t]{2}{*}{ SMW* } & \multirow[t]{2}{*}{ Date } & \multirow[t]{2}{*}{$\begin{array}{l}\text { Phenological } \\
\text { Stage of the } \\
\text { crop (days) }\end{array}$} & \multicolumn{2}{|c|}{$\begin{array}{c}\text { Temperature } \\
\left({ }^{0} \mathrm{C}\right)\end{array}$} & \multirow[t]{2}{*}{$\begin{array}{l}\text { Rainfall } \\
\text { (mm) }\end{array}$} & \multirow[t]{2}{*}{$\begin{array}{l}\text { Sunshine } \\
\text { hours } \\
\text { (hrs/day) }\end{array}$} & \multicolumn{2}{|c|}{$\begin{array}{c}\text { Relative } \\
\text { humidity } \\
(\%)\end{array}$} & \multirow{2}{*}{$\begin{array}{l}\text { Anthracnose } \\
\text { (PDI) } \\
\text { Sel - } 4\end{array}$} \\
\hline & & & & Max. & Min. & & & RH I & RH-II & \\
\hline 1 & 30 & July 23-29 & $6-12$ & 34.3 & 24.2 & 2.00 & 2.0 & 82.40 & 51.30 & 0.00 \\
\hline 2 & 31 & July 30-Aug 05 & $13-19$ & 34.8 & 24.1 & 3.30 & 2.4 & 79.00 & 50.00 & 7.50 \\
\hline 3 & 32 & Aug 06-12 & $20-26$ & 33.9 & 23.9 & 11.50 & 1.8 & 79.00 & 53.00 & 16.43 \\
\hline 4 & 33 & Aug 13-19 & $27-33$ & 30.4 & 23.1 & 18.80 & 0.7 & 85.30 & 68.00 & 18.50 \\
\hline 5 & 34 & Aug 20-26 & $34-40$ & 33.1 & 23.0 & 1.00 & 5.0 & 87.00 & 51.70 & 28.32 \\
\hline 6 & 35 & Aug 27- Sept 02 & $41-47$ & 32.6 & 22.7 & 21.20 & 4.3 & 89.00 & 54.30 & 36.75 \\
\hline 7 & 36 & Sept 03-09 & $48-54$ & 33.8 & 22.5 & 0.00 & 6.5 & 77.00 & 48.00 & 42.12 \\
\hline 8 & 37 & Sept $10-16$ & $55-61$ & 35.1 & 23.9 & 8.50 & 6.2 & 74.10 & 43.30 & 49.65 \\
\hline 9 & 38 & Sept $17-23$ & $62-68$ & 32.4 & 22.7 & 47.00 & 4.0 & 83.40 & 55.00 & 58.02 \\
\hline \multicolumn{4}{|c|}{ Total / Average } & 33.3 & 23.3 & 113.30 & 3.65 & 81.80 & 52.73 & 28.58 \\
\hline
\end{tabular}

*SMW - Standard Meteorological Week DOS - Date of Sowing

Table.3a The data of weather parameters and percent disease index of greengram anthracnose during crop sown on $8^{\text {th }}$ August, $2018\left(2^{\text {nd }}\right.$ DOS $)$

\begin{tabular}{|c|c|c|c|c|c|c|c|c|c|c|}
\hline \multirow[t]{2}{*}{$\begin{array}{l}\text { Sl. } \\
\text { No }\end{array}$} & \multirow[t]{2}{*}{$\underset{*}{\text { SMW }}$} & \multirow[t]{2}{*}{ Date } & \multirow[t]{2}{*}{$\begin{array}{l}\text { Phenological } \\
\text { Stage of the } \\
\text { crop }\end{array}$} & \multicolumn{2}{|c|}{$\begin{array}{c}\text { Temperature } \\
\left({ }^{0} \mathrm{C}\right)\end{array}$} & \multirow[t]{2}{*}{$\begin{array}{c}\text { Rainfall } \\
\text { (mm) }\end{array}$} & \multirow[t]{2}{*}{$\begin{array}{l}\text { Sunshin } \\
\text { e hours } \\
\text { (h/day) }\end{array}$} & \multicolumn{2}{|c|}{$\begin{array}{c}\text { Relative } \\
\text { humidity } \\
(\%)\end{array}$} & \multirow{2}{*}{$\begin{array}{c}\text { Anthracnos } \\
\text { e } \\
\text { (PDI) } \\
\text { Sel }-4\end{array}$} \\
\hline & & & & Max. & Min. & & & RH I & RH-II & \\
\hline 1 & 32 & Aug 06-12 & $6-12$ & 33.9 & 23.9 & 11.5 & 1.8 & 79.00 & 53.00 & 0 \\
\hline 2 & 33 & Aug 13-19 & $13-19$ & 30.4 & 23.1 & 18.8 & 0.7 & 85.30 & 68.00 & 17.50 \\
\hline 3 & 34 & Aug 20-26 & $20-26$ & 33.1 & 23.0 & 1.00 & 5.0 & 87.00 & 51.7 & 24.90 \\
\hline 4 & 35 & Aug 27- Sept 02 & $27-33$ & 32.6 & 22.7 & 21.2 & 4.3 & 89.00 & 54.3 & 36.42 \\
\hline 5 & 36 & Sept 03-09 & $34-40$ & 33.8 & 22.5 & 0.00 & 6.5 & 77.00 & 48.00 & 39.65 \\
\hline 6 & 37 & Sept $10-16$ & $41-47$ & 35.1 & 23.9 & 8.50 & 6.2 & 74.10 & 43.30 & 42.56 \\
\hline 7 & 38 & Sept $17-23$ & $48-54$ & 32.4 & 22.7 & 47.0 & 4.0 & 83.40 & 55.00 & 49.21 \\
\hline 8 & 39 & Sept 24-30 & $55-61$ & 32.7 & 23.7 & 21.6 & 6.8 & 87.00 & 53.00 & 57.65 \\
\hline 9 & 40 & Oct $01-07$ & $62-68$ & 33.7 & 24.4 & 0.00 & 8.3 & 75.4 & 52.00 & 63.23 \\
\hline \multicolumn{4}{|c|}{ Total / Average } & 33.07 & 23.32 & 129.6 & 4.8 & 81.91 & 53.10 & 36.79 \\
\hline
\end{tabular}

*SMW - Standard Meteorological Week DOS - Date of Sowing 
Table.4a The data of weather parameters and per cent disease index of greengram anthracnose during crop sown on $13^{\text {th }}$ August, $2018\left(3^{\text {rd }}\right.$ DOS)

\begin{tabular}{|c|c|c|c|c|c|c|c|c|c|c|}
\hline \multirow[t]{2}{*}{$\begin{array}{l}\text { Sl. } \\
\text { No. }\end{array}$} & \multirow[t]{2}{*}{ SMW } & \multirow[t]{2}{*}{ Date } & \multirow[t]{2}{*}{$\begin{array}{l}\text { Phenological } \\
\text { Stage of the } \\
\text { crop }\end{array}$} & \multicolumn{2}{|c|}{$\begin{array}{c}\text { Temperature } \\
\left({ }^{0} \mathrm{C}\right)\end{array}$} & \multirow[t]{2}{*}{$\begin{array}{c}\text { Rainfall } \\
\text { (mm) }\end{array}$} & \multirow[t]{2}{*}{$\begin{array}{c}\text { Sunshine } \\
\text { hours } \\
\text { (hrs/day) }\end{array}$} & \multicolumn{2}{|c|}{$\begin{array}{c}\text { Relative } \\
\text { humidity } \\
(\%)\end{array}$} & \multirow{2}{*}{$\begin{array}{l}\text { Anthracnose } \\
\text { (PDI) } \\
\text { Sel - } 4\end{array}$} \\
\hline & & & & Max. & Min. & & & RH I & RH-II & \\
\hline $\mathbf{1}$ & 33 & Aug 13-19 & $6-12$ & 30.4 & 23.1 & 18.8 & 0.7 & 85.30 & 68.00 & 0 \\
\hline 2 & 34 & Aug 20-26 & $13-19$ & 33.1 & 23.0 & 1.00 & 5.0 & 87.00 & 51.70 & 18.50 \\
\hline 3 & 35 & $\begin{array}{c}\text { Aug 27- Sept } \\
02\end{array}$ & $20-26$ & 32.6 & 22.7 & 21.2 & 4.3 & 89.00 & 54.30 & 26.32 \\
\hline 4 & 36 & Sept 03-09 & $27-33$ & 33.8 & 22.5 & 0.00 & 6.5 & 77.00 & 48.00 & 33.65 \\
\hline 5 & 37 & Sept $10-16$ & $34-40$ & 35.1 & 23.9 & 8.50 & 6.2 & 74.10 & 43.30 & 40.58 \\
\hline 6 & 38 & Sept $17-23$ & $41-47$ & 32.4 & 22.7 & 47.0 & 4.0 & 83.40 & 55.00 & 46.14 \\
\hline 7 & 39 & Sept $24-30$ & $48-54$ & 32.7 & 23.7 & 21.6 & 6.8 & 87.00 & 53.00 & 56.11 \\
\hline 8 & 40 & Oct 01-07 & $55-61$ & 33.7 & 24.4 & 0.00 & 8.3 & 75.40 & 52.00 & 61.02 \\
\hline 9 & 41 & Oct $08-14$ & $62-68$ & 34.8 & 20.8 & 3.2 & 6.8 & 71.00 & 36.10 & 69.65 \\
\hline \multicolumn{4}{|c|}{ Total / Average } & 33.17 & 22.97 & 121.3 & 5.4 & 81.02 & 51.26 & 39.10 \\
\hline
\end{tabular}

*SMW - Standard Meteorological Week DOS - Date of Sowing

Table.2b Correlation coefficients between weather parameters and per cent disease index of greengram anthracnose during the crop sown on $29^{\text {th }}$ July, $2018\left(1^{\text {st }} \mathrm{DOS}\right)$

\begin{tabular}{|c|c|c|c|c|c|c|c|}
\hline Parameters & $\mathbf{Y}$ & X1 & $\mathrm{X} 2$ & X3 & X4 & X5 & $\mathbf{X}_{6}$ \\
\hline $\begin{array}{c}\text { Y } \\
\text { PDI }\end{array}$ & 1 & & & & & & \\
\hline $\begin{array}{c}\mathrm{X}_{1} \\
\text { Maximum temperature }\left({ }^{\circ} \mathrm{C}\right)\end{array}$ & -0.113 & 1 & & & & & \\
\hline $\begin{array}{c}\mathbf{X}_{2} \\
\text { Minimum temperature }\left({ }^{\circ} \mathrm{C}\right)\end{array}$ & -0.648 & 0.602 & 1 & & & & \\
\hline $\begin{array}{c}\mathbf{X}_{3} \\
\text { Rainfall (mm) }\end{array}$ & 0.543 & -0.526 & -0.414 & 1 & & & \\
\hline $\begin{array}{c}\mathrm{X}_{4} \\
\text { Sunshine hours (h/day) }\end{array}$ & $0.728^{*}$ & 0.375 & -0.432 & -0.128 & 1 & & \\
\hline $\begin{array}{l}\mathrm{X}_{5} \\
\text { Relative humidity (morning) (\%) }\end{array}$ & -0.107 & $-0.681^{*}$ & -0.447 & 0.311 & -0.283 & 1 & \\
\hline $\begin{array}{c}\mathrm{X}_{6} \\
\text { Relative humidity (evening) (\%) }\end{array}$ & -0.227 & $-0.921 * *$ & -0.286 & 0.415 & -0.697 & 0.606 & 1 \\
\hline
\end{tabular}


Table.3b Correlation coefficients between weather parameters and per cent disease index of greengram anthracnose during the crop sown on $8^{\text {th }}$ August, 2018 ( $2^{\text {nd }}$ DOS $)$

\begin{tabular}{|c|c|c|c|c|c|c|c|}
\hline Parameters & $\mathbf{Y}$ & $\mathbf{X 1}$ & $\mathbf{X} 2$ & $\mathbf{X} 3$ & X4 & X5 & $\mathbf{X}_{6}$ \\
\hline $\begin{array}{c}\text { Y } \\
\text { PDI }\end{array}$ & 1 & & & & & & \\
\hline $\begin{array}{c}\mathrm{X}_{1} \\
\text { Maximum } \\
\text { temperature }\left({ }^{\circ} \mathrm{C}\right)\end{array}$ & 0.168 & 1 & & & & & \\
\hline $\begin{array}{c}\mathrm{X}_{2} \\
\text { Minimum } \\
\text { temperature }\left({ }^{\circ} \mathrm{C}\right)\end{array}$ & 0.156 & 0.412 & 1 & & & & \\
\hline $\begin{array}{c}\mathbf{X}_{3} \\
\text { Rainfall (mm) }\end{array}$ & 0.115 & -0.468 & -0.338 & 1 & & & \\
\hline $\begin{array}{c}\mathrm{X}_{4} \\
\substack{\text { Sunshine hours } \\
\text { (h/day) }}\end{array}$ & $0.830 * *$ & 0.578 & 0.295 & -0.374 & 1 & & \\
\hline $\begin{array}{c}\mathrm{X}_{4} \\
\text { Relative humidity } \\
\text { (morning) }(\%)\end{array}$ & -0.143 & $-0.687 *$ & -0.492 & 0.423 & -0.359 & 1 & \\
\hline $\begin{array}{c}\mathrm{X}_{5} \\
\text { Relative humidity } \\
\text { (evening) (\%) }\end{array}$ & -0.332 & $-0.952 * *$ & -0.219 & 0.378 & $-0.695 *$ & 0.538 & 1 \\
\hline
\end{tabular}

Table.4b Correlation coefficients between weather parameters and per cent disease index of greengram anthracnose during the crop sown on $13^{\text {th }}$ August, 2018 ( $3^{\text {rd }}$ DOS $)$

\begin{tabular}{|c|c|c|c|c|c|c|c|}
\hline Parameters & $\mathbf{Y}$ & X1 & $\mathbf{X} 2$ & X3 & $\mathrm{X} 4$ & X5 & $X_{6}$ \\
\hline $\begin{array}{c}\text { Y } \\
\text { PDI }\end{array}$ & 1 & & & & & & \\
\hline $\begin{array}{c}\mathrm{X}_{1} \\
\text { Maximum } \\
\text { temperature }\left({ }^{\circ} \mathrm{C}\right)\end{array}$ & 0.661 & 1 & & & & & \\
\hline $\begin{array}{c}\mathrm{X}_{2} \\
\text { Minimum } \\
\text { temperature }\left({ }^{\circ} \mathrm{C}\right)\end{array}$ & -0.125 & -0.140 & 1 & & & & \\
\hline $\begin{array}{c}X_{3} \\
\text { Rainfall (mm) }\end{array}$ & -0.80 & -0.514 & -0.001 & 1 & & & \\
\hline $\begin{array}{c}\mathbf{X}_{\mathbf{4}} \\
\text { Sunshine hours } \\
\text { (hrs/day) }\end{array}$ & $0.818 * *$ & $0.804 * *$ & 0.131 & -0.494 & 1 & & \\
\hline $\begin{array}{c}\mathrm{X}_{4} \\
\text { Relative humidity } \\
\text { (morning) }(\%)\end{array}$ & -0.583 & $-0.745^{*}$ & 0.209 & 0.475 & -0.547 & 1 & \\
\hline $\begin{array}{c}\mathbf{X}_{5} \\
\text { Relative humidity } \\
\text { (evening) }(\%)\end{array}$ & $-0.705^{*}$ & $-0.954 * *$ & 0.402 & 0.441 & $-0.736 *$ & $0.708^{*}$ & 1 \\
\hline
\end{tabular}

**. Correlation is significant at the 0.01 level (2-tailed); *. Correlation is significant at the 0.05 level (2-tailed). 
Table.5 Effect of elevated carbon dioxide and temperature on disease severity of anthracnose of greengram caused by Colletotrichum truncatum

\begin{tabular}{|c|c|c|c|c|}
\hline Treatments & $\begin{array}{l}\text { Height of the } \\
\text { plant }(\mathrm{cm})\end{array}$ & $\begin{array}{c}\text { No. of leaves per } \\
\text { plant }\end{array}$ & $\begin{array}{c}\text { No. of pods per } \\
\text { plant }\end{array}$ & $\begin{array}{l}\text { *Disease } \\
\text { severity }\end{array}$ \\
\hline $\begin{array}{c}\mathrm{T}_{1}: \text { Elevated } \mathrm{CO}_{2} \text { at } \\
550 \pm 25 \mathrm{ppm} \\
\text { with normal } \\
\text { temperature }\end{array}$ & 30.80 & 29.60 & 15.20 & 3.25 \\
\hline $\begin{array}{c}\mathrm{T}_{2}: \text { Elevated } \mathrm{CO}_{2} \text { at } \\
550 \pm 25 \mathrm{ppm} \\
\text { with } 2^{\circ} \mathrm{C} \text { rise in } \\
\text { temperature }\end{array}$ & 29.20 & 27.80 & 14.20 & 3.75 \\
\hline $\begin{array}{c}\mathrm{T}_{3}: \text { Ambient } \mathrm{CO}_{2} \text { at } \\
410 \pm 25 \mathrm{ppm} \\
\text { with } 2^{\circ} \mathrm{C} \text { rise in } \\
\text { temperature }\end{array}$ & 29.00 & 26.40 & 12.40 & 7.00 \\
\hline $\begin{array}{c}\mathrm{T}_{4}: \text { Reference open } \\
\text { top chamber }\end{array}$ & 31.20 & 30.40 & 17.80 & 3.00 \\
\hline $\mathrm{T}_{5}:$ Open plot & 33.80 & 31.20 & 19.20 & 2.50 \\
\hline S em & 0.69 & 0.64 & 0.98 & 0.38 \\
\hline CD at $1 \%$ & 2.76 & 2.58 & 3.95 & 1.47 \\
\hline
\end{tabular}

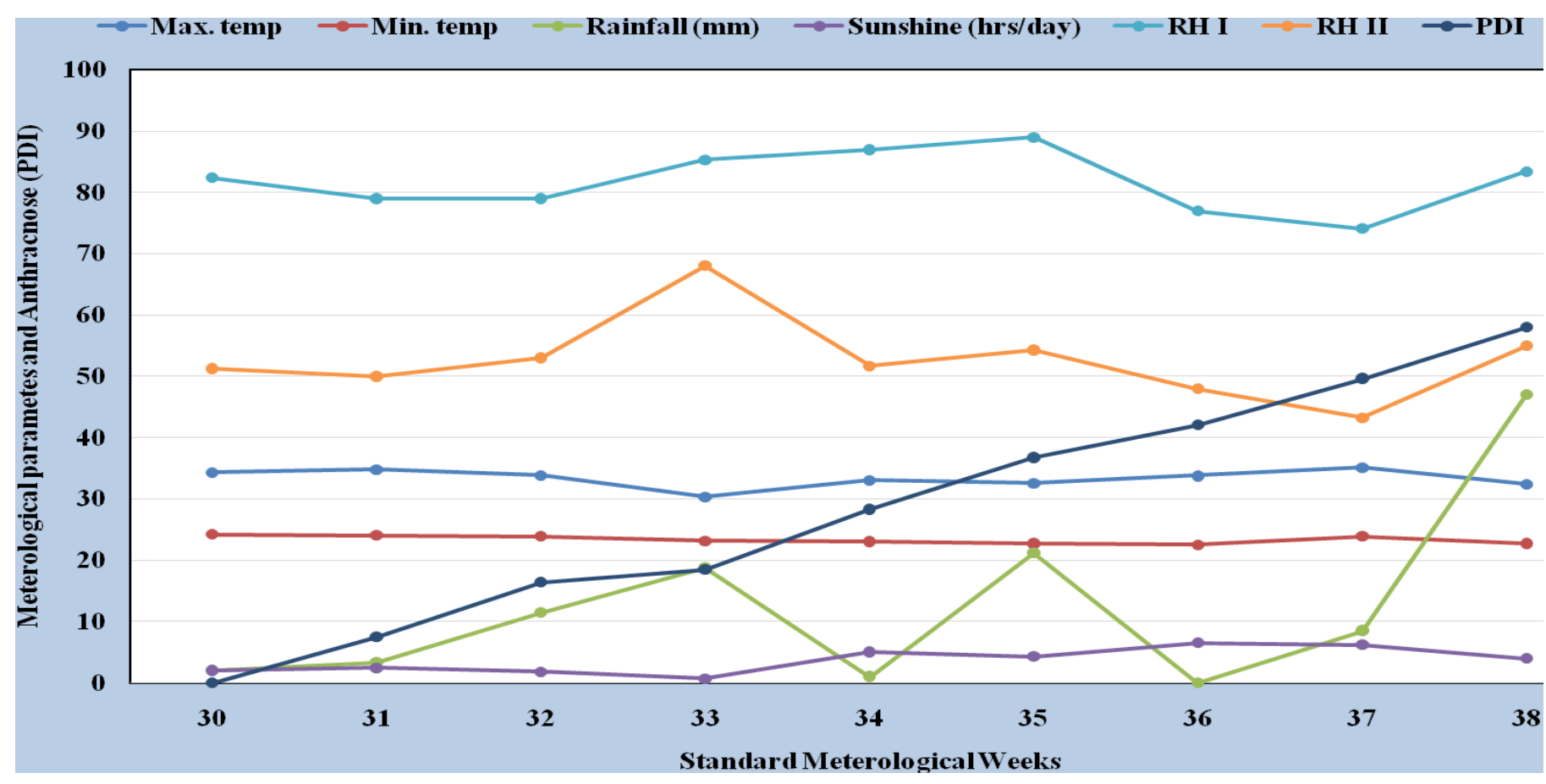

Fig.1 Influence of weather parameters on greengram anthracnose during crop sown on $29^{\text {th }}$ July, $2018\left(1^{\text {st }}\right.$ DOS $)$ 


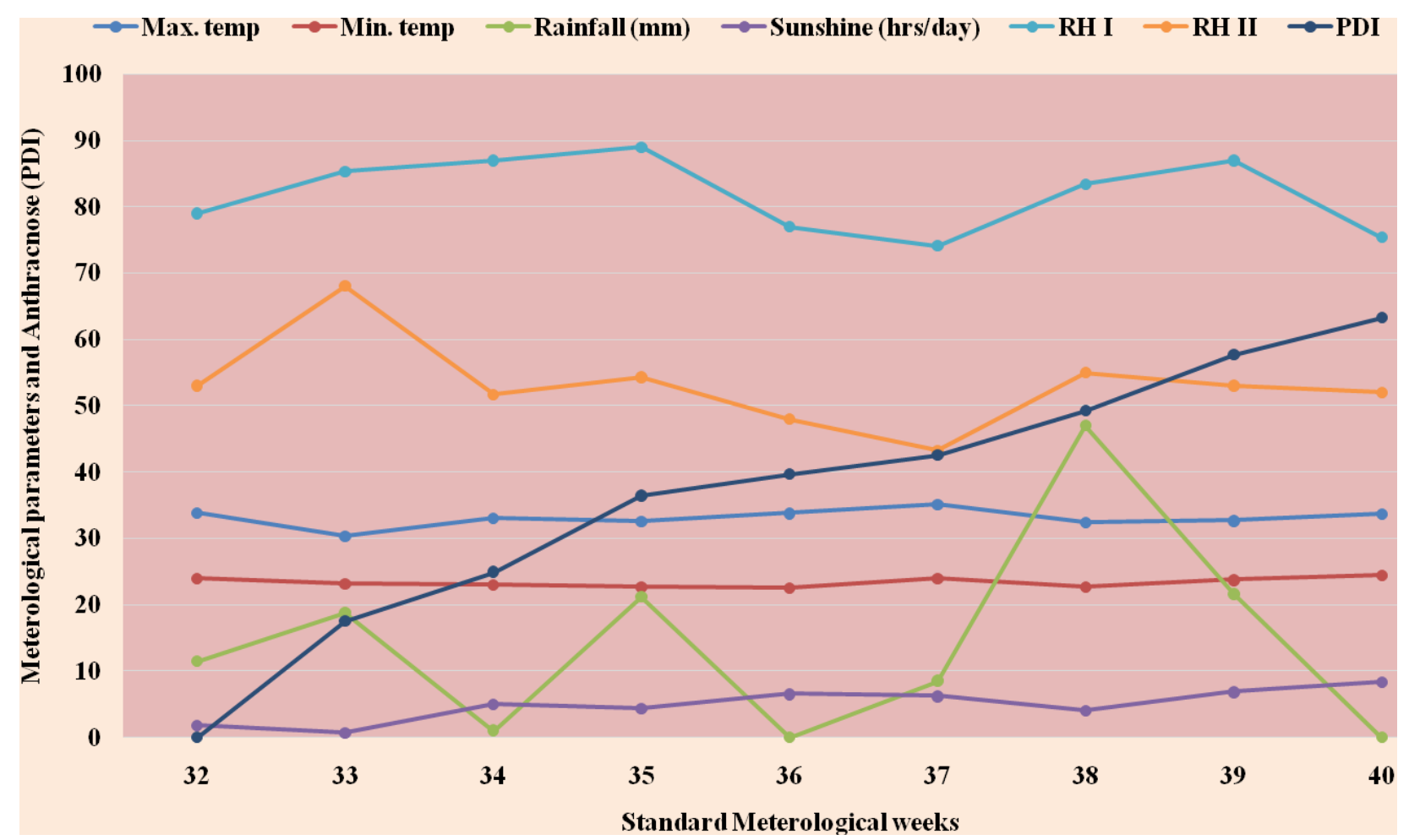

Fig.2 Influence of weather parameters on greengram anthracnose during crop sown on $8^{\text {th }}$ August, $2018\left(2^{\text {nd }}\right.$ DOS $)$

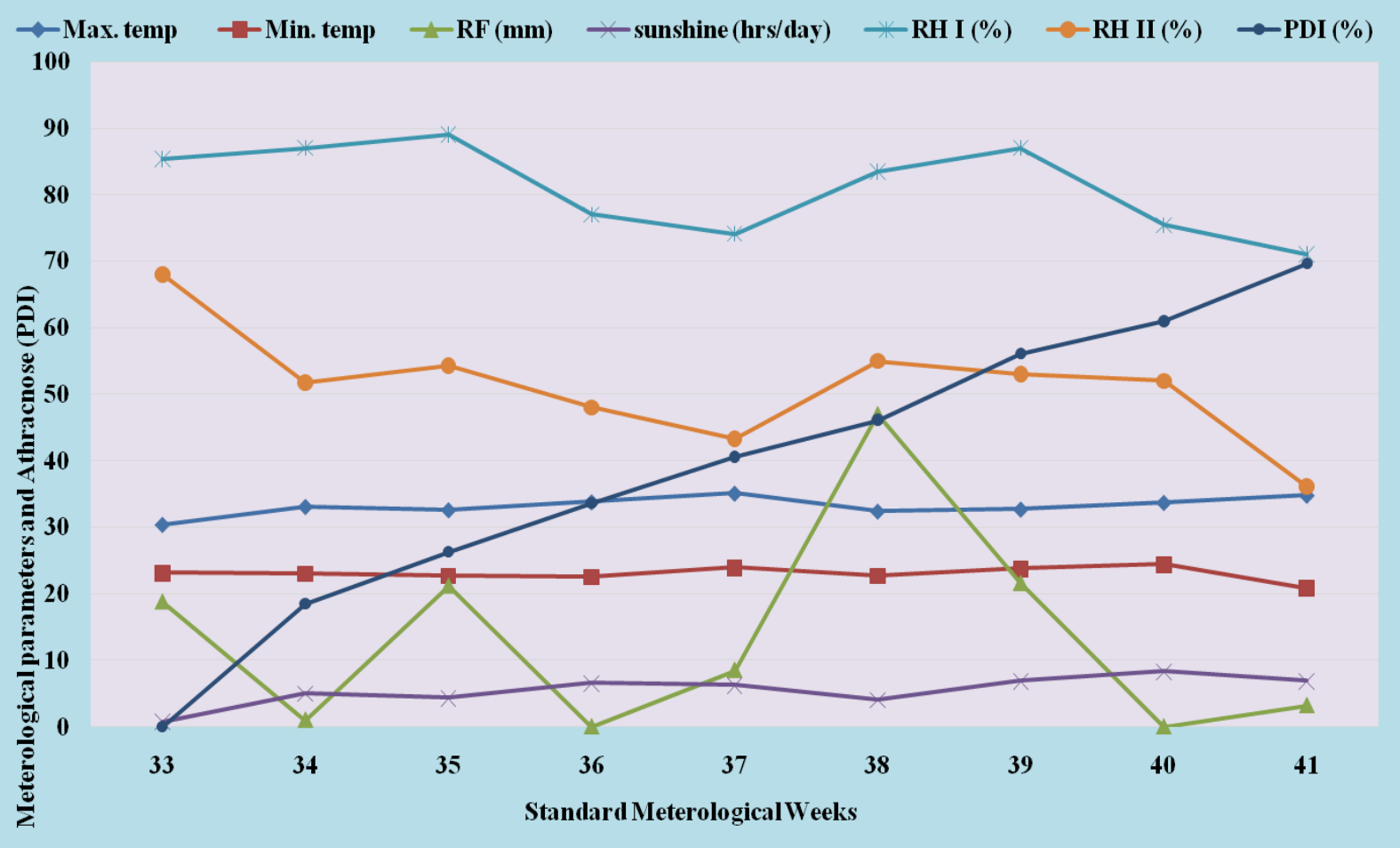

Fig.3 Influence of weather parameters on greengram anthracnose during crop sown on $13^{\text {th }}$ August, $2018\left(3^{\text {rd }}\right.$ DOS $)$ 


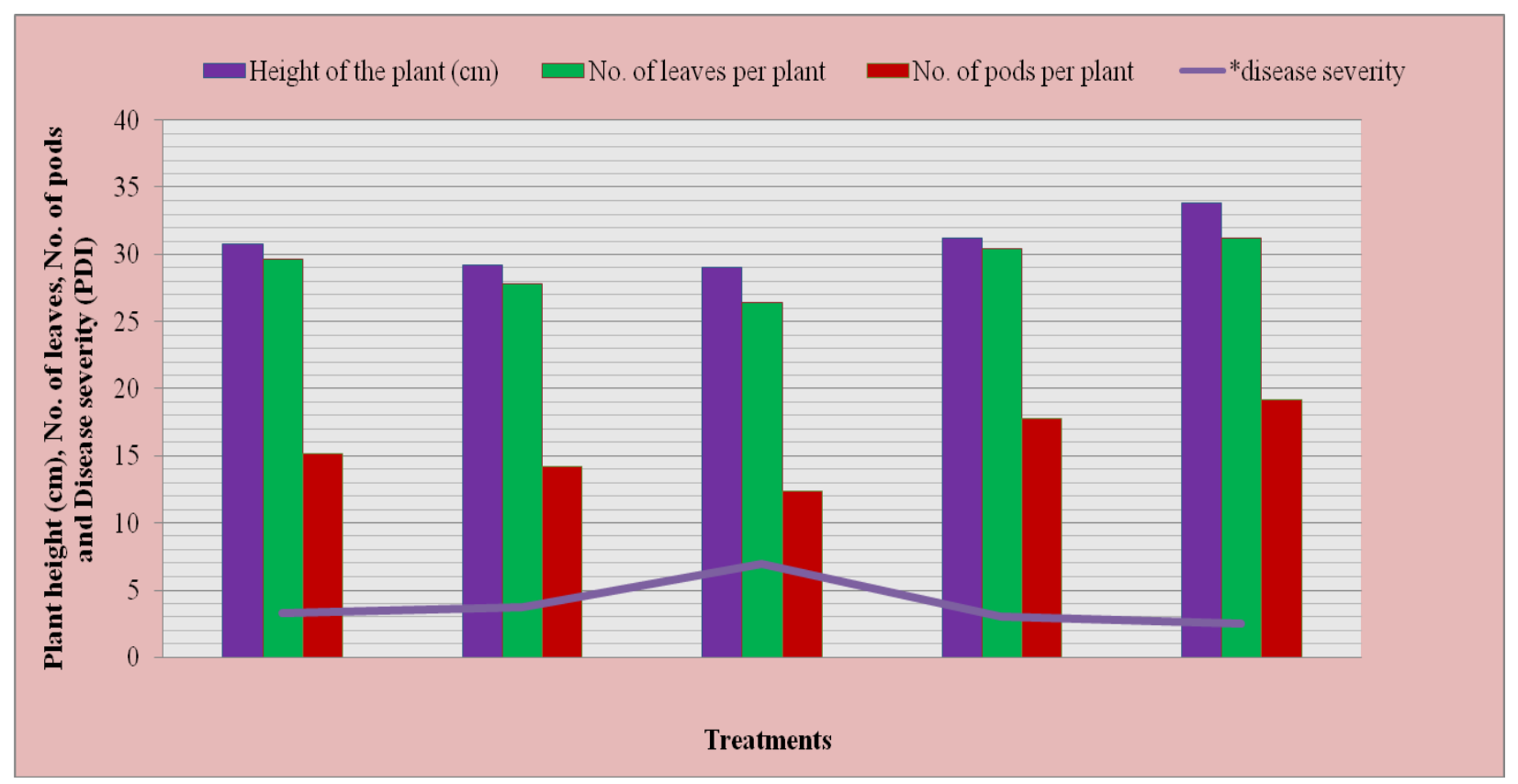

Fig.4 Effect of elevated $\mathrm{CO}_{2}$ and temperature on disease severity and growth parameters of greengram anthracnose

$\mathrm{T}_{1}$ : Elevated $\mathrm{CO}_{2}$ at $550 \pm 25 \mathrm{ppm}$ with normal temperature

$\mathrm{T}_{2}$ : Elevated $\mathrm{CO}_{2}$ at $550 \pm 25 \mathrm{ppm}$ with $2^{\circ} \mathrm{C}$ rise in temperature

$\mathrm{T}_{3}$ : Ambient $\mathrm{CO}_{2}$ at $410 \pm 25 \mathrm{ppm}$ with $2^{\circ} \mathrm{C}$ rise in temperature

$\mathrm{T}_{4}$ : Reference open top chamber

$\mathrm{T}_{5}$ : Open plot

The results clearly indicates that disease severity was minimum during the crop sown on $29^{\text {th }}$ July with higher yields when compared with crop sown on $13^{\text {th }}$ August due to favourable weather conditions led to build up the inoculum and has spread the disease. Maximum temperature, minimum temperature, morning relative humidity and evening relative humidity were found negatively correlated with disease severity, whereas rainfall and sunshine hours showed significant positive correlation with disease severity.

However interaction of weather parameters, relative humidity (morning and evening) compiled with rainfall have shown positive correlation with disease severity. The studies on effect of $\mathrm{CO}_{2}$ on disease severity revealed that, at ambient $\mathrm{CO}_{2}$ at $410 \pm 25 \mathrm{ppm}$ with $2^{\circ} \mathrm{C}$ rise in temperature showed higher disease severity of 7.00 per cent with reduced growth parameters.

\section{References}

Afzal, M. A., Murshad, A. N. M. M., Bakar, M. M. A., Hamid, A. and Salahuddin, A. B. M., 2008, Mungbean cultivation in Bangladesh, Pulse Research Station, Bangladesh Agricultural Research Institute, Gazipur, Bangladesh, 13.

Anonymous, 2018, Agricultural Statistics at a Glance, Ministry of Agriculture, Government of India.

Deeksha, J. and Tripathi, H. S., 2002, Perpetuation of Colletotrichum capsici in infected seeds and crop debris of urd bean. J. Mycol. and Pl. Pathol., 32(1): 28-30.

Jeong, W. S. and Sung C. Y., 2010, Elevated $\mathrm{CO}_{2}$ and temperature effects on the 
incidence of four major chili pepper diseases, Pl. Pathol. J., 26(2) : 178-184.

Kulkarni, S. A. and Benagi, V. I., 2012, Effect of date on sowing and correlation of weather parameters on the incidence of anthracnose of greengram. Internat. J. Plant Protec., 5(2): 349-351.

Laxman, R., 2006, Studies on leaf spot of greengram caused by Colletotrichum truncatum (Schw.) Andrus and Moore. M. Sc. (Agri.) Thesis, Univ. Agric. Sci., Dharwad (India).

Majid, S., 1953, Annu. Reptr. Dept. Agric., Assam for year ending 31st March 1950. II. The Grow More Food
Campaign 11: 107.

Mangilal, K., 2014, Studies on anthracnose [Colletotrichum truncatum (Schw.) Andrus and Moore] of Mungbean. $M$. Sc. (Agri.) Thesis, Rajmata Vijayaraje Scindia Krishi Vishwa Vidyalaya, College of Agriculture, Indore (India).

Murakami, T., Siripin, S., Wadisirisuk, P. Boonkerd, N., Yoneyama, T., Yokoyama, T. and Imai, H., 1991, The nitrogen fixing ability of mung bean (Vigna radiata). In: Proceedings of the Mungbean Meeting, pp. 187-198. Chiang Mai, Thailand.

\section{How to cite this article:}

Rajashree G, M. B. Patil, D. S. Aswathanaryana, K. Mallikarjun and Sreenivas. A. G. 2020. Effect of Date of Sowing and Climate Change Variables on Greengram [Vigna Radiata(L.) Wilczek] Anthracnose Caused by Colletotrichum Truncatum. Int.J.Curr.Microbiol.App.Sci. 9(03): 1610-1621. doi: https://doi.org/10.20546/ijcmas.2020.903.189 